\section{Root Pruning Pin Oak Liners Affects Growth and Root Morphology}

\author{
J. Roger Harris, ${ }^{1}$ Jody Fanelli, ${ }^{2}$ \\ Alex Niemiera, ${ }^{1}$ and \\ Robert Wright ${ }^{3}$
}

ADITIONAL INDEX WORDS. nursery, container, root length, rootball, transplant

Summary. Two experiments tested the effects of root pruning on growth during first-season production of pin oak (Quercus palustris Muenchh.). Experiment one tested the effect of root pruning developing radicles at $\mathbf{5}$, 10 , or $15 \mathrm{~cm}(2,4$, or 6 inches) below the substrate surface. After 11 weeks, total root length was not affected by root pruning, but root-pruned seedlings had more main lateral [ $>2$ $\mathrm{mm}(0.08$-inch $)$ diameter] roots than those that were not root pruned. Shallow pruning increased the number of main lateral roots. Experiment two tested the effect of initially producing plants in different-depth bottomless containers $[5,10,15$, or 20 -cm $(2,4,6$, or 8-inch) depth] on growth after transplanting to \#2 [6 L (1.6 gal)] containers. Shoot and root growth in \#2 containers were lowest when plants were originally produced in 5-cm-deep containers. Plants with the greatest height and highest root:shoot ratios were obtained when plants were grown initially in $10-\mathrm{cm}$ deep containers. Predicted optimum depth of bottomless containers from regression equations ranged from $11.3 \mathrm{~cm}(4.5$ inches $)$ to $14.2 \mathrm{~cm}(5.5$ inches) for the different growth

This research was funded in part by a grant from the Virginia Nursery and Landscape Association. The cost of publishing this paper was defrayed in part by the payment of page charges. Under postal regulations, this paper therefore must be hereby marked advertisement solely to indicate this fact.

${ }^{1}$ Associate Professor, Department of Horticulture, Virginia Polytechnic and State University, Blacksburg VA 24061.

${ }^{2}$ Research Technician, Department of Horticulture, Virginia Polytechnic and State University, Blacksburg VA 24061.

${ }^{3}$ Professor. Department of Horticulture. Virginia Polytechnic Institute and State University. Blacksburg, VA 24061. parameters measured. The importance of these findings are: Pruning developing radicles of pin oak seedlings increases the number of main lateral roots but not overall root length. Growers can maximize growth in \#2 containers by initially growing in 10$\mathrm{cm}$-deep bottomless containers before transplanting to \#2 containers.

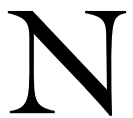

ursery operators have long sought to increase outplanting survival and growth by root pruning young plants (Duryea and Landis, 1984; Harris et al., 1971). Some report increased survival and growth (Benson and Shepherd, 1977; Hipps et al., 1999) while others report no effect (Harris and Fanelli, 1998; Hipps et al., 1996) from root pruning. A pretransplant increase in the root:shoot ratio of young plants (liners) is considered advantageous for outplanting (Kozlowski and Pallardy, 1997). Increased ratios usually result when liners are root pruned during production (Hipps et al., 1997; Rook, 1971; Tanaka et al., 1976), although some studies reported no effect (Duryea and Lavender, 1982; Hipps et al., 1997). Root pruning field-grown landscape trees is also a recommended practice (Watson, 1986). Root pruning colorado blue spruce (Picea pungens Engel.) 5 years before transplanting increased four fold the root surface area within rootballs (Watson and Sydnor, 1987), and fall root pruning of live oak (Quercus virginiana L.) increased fine root growth within rootballs of spring-harvested trees (Gilman and Yeager, 1987). Although root pruning larger, field-grown nursery stock may increase root fibrosity and root:shoot ratios, posttransplant growth may be unaffected (Gilman and Kane, 1990).

The use of copper compounds as root pruning agents (Pellet et al., 1980; Ruehle, 1985; Stinson and Keys, 1953) was further developed by Arnold and Struve (Arnold and Struve, 1989). Containers treated with copper-based paints are now commonly used by growers to reduce root circling and to increase root system fibrosity (Struve et al., 1994). Plant response is speciesspecific (Beeson and Newton, 1992). Liner production in bottomless containers is a root pruning method that root prunes by desiccation when roots reach the substrate:air interface (Hathaway and Whitcomb, 1977).
This root pruning presumably results in a more branched (i.e. fibrous) root system, which may facilitate field transplanting and container production.

Oak seedlings develop taproots shortly after germination (Burns and Honkala, 1990), and root pruning of young liners is suggested (Hartmann et al., 1997). Our objective was to investigate root pruning strategy for production of pin oak liners. Experiment one tested the effect of pruning developing radicles at various lengths on root development and shoot growth, whereas experiment two tested the effect of initially growing liners in bottomless containers of varying depths on root and shoot growth after transplanting to \#2 containers.

\section{Materials and methods}

EXPERIMENT ONE. We fashioned growing containers from $20-\mathrm{cm}$-long, $5-\mathrm{cm}$-diameter polyvinyl chloride (PVC) pipe and 5-cm-diameter, clear polyethylene (0.1-mm thickness) tubes (Chiswick, Sudbury, Md.) that served as inserts. The bottom of each insert was heat-sealed, and two drainage holes (about 7-mm (0.28-inch) diameter) were punched through the bottom. The pipes with inserts were filled with $100 \%$ pine-bark $(\mathrm{pH}=5.1)$ substrate incorporated with $5 \mathrm{~kg} \cdot \mathrm{m}^{-3}(8.5 \mathrm{lb} /$ yard $^{3}$ ) of slow-release fertilizer (Osmocote Plus 15N-3.8P-10K, The Scotts Company, Marysville, Ohio). Bark physical properties (Niemiera et al., 1994) were: air space $=24.3 \%$; bulk density $=200 \mathrm{~kg} \cdot \mathrm{m}^{-3}\left(337 \mathrm{lb} /\right.$ yard $\left.^{3}\right)$; total porosity $=79.8 \%$; container $($ water holding) capacity $=55.5 \%$. This created a system where inserts could be easily removed from the PVC pipe sections for quick observation of root growth.

Acorns obtained from Sheffield Seed Co. (Locke, N.Y.) were coldstratified for about 3 months and then germinated in open flats of vermiculite. On 12 May 1998, randomly selected acorns with about $13-\mathrm{mm}(0.5-$ inch) long radicles were singly placed just below the substrate surface in each of 40 containers. Seedlings were grown with the containers tilted at $45^{\circ}$ so that developing root systems could be more easily observed against the insert walls.

Four treatments were randomly assigned to the developing seedlings: 1) radicle cut when it reached $5 \mathrm{~cm}$ below the substrate surface, 2 ) radicle cut at $10 \mathrm{~cm}, 3$ ) radicle cut at $15 \mathrm{~cm}$, 
Table 1. Effect of radicle tip removal at various substrate depths on numbers of main lateral roots of pin oak; $\mathbf{n}=10$

\begin{tabular}{lc}
\hline Depth of cut & Main laterals \\
\hline $5 \mathrm{~cm}$ (2 inches) & 4.8 \\
$10 \mathrm{~cm}$ (4 inches) & 4.0 \\
$15 \mathrm{~cm}$ (6 inches) & 2.0 \\
Not cut & 1.7 \\
& $P$ value \\
Cut versus not cut & 0.004 \\
Linear (cut only) & 0.005 \\
\hline
\end{tabular}

${ }^{\mathrm{z}}$ All plants were grown in 20-cm (8-inch) deep contain ers.

${ }^{y} P>F$ for control versus all others and linear effect for plants with cut radicles. Numbers were transformed to square roots for analysis. Actual root numbers are presented.

and 4) radicle not cut. Radicles were cut at the depth described through a slit made through the insert side wall with a razor blade and slits were then covered with clear tape. Root growth was checked daily throughout the experiment. The amount of tip removed ranged from $0.6 \mathrm{~cm}(0.25$ inch $)$ to 2.5 $\mathrm{cm}$ ( 1 inch). Seedlings were monitored daily and irrigated so as to maintain substrate near container capacity.

On 30 July, all plants were harvested. The number of new roots (main lateral, $>2 \mathrm{~mm}$ in diameter at origin) emerging after pruning from the radicle were recorded and, after plant heights were measured, shoots (all tissue above the substrate) were dried to a constant weight at $70^{\circ} \mathrm{C}\left(158^{\circ} \mathrm{F}\right)$. Root length was measured for each tree with the Delta-T system (Delta-T Devices Ltd. Cambridge, England), and roots were then dried to a constant weight at 70 ${ }^{\circ} \mathrm{C}$.

The entire experiment, as well as the one described below, was conducted in a glass greenhouse (day/ night temperature $=22^{\circ} \mathrm{C}\left(72^{\circ} \mathrm{F}\right) / 20$ ${ }^{\circ} \mathrm{C}\left(68^{\circ} \mathrm{F}\right)$ on the Virginia Tech campus in Blacksburg, Va. All growth data were analyzed with the GLM procedure of SAS, version 6.12 (SAS Institute, Cary, N.C.). Main lateral root numbers were transformed to square roots (Mead et al., 1993) and analyzed with the GLM procedure of SAS and the regression procedure of Minitab, version 12 (Minitab, Inc., State College, Pa.).

EXPERIMENT two. Containers were made with 5-cm-diameter PVC pipe that was cut into $5,10,15$, or $20-\mathrm{cm}$ lengths and filled with nutrient- amended substrate as described for experiment one. The bottom of each pipe section was covered with cheese cloth (attached with clear tape to outside of container sidewalls), creating a bottomless container. These containers ( 10 of each length $=40$ total $)$ were randomly arranged and held upright by placing them in holes drilled through a sheet of plywood. A pregerminated acorn was placed just below the substrate surface in each container on 12 May 1998. Periodically, rootballs were gently checked to determine when they could be removed intact.

When all plants in a treatment (container size) were determined to have intact rootballs, they were repotted into \#2 nursery containers (600C, Nursery Supplies, Inc., Fairles Hills, N.C.) on the following dates: 5 $\mathrm{cm}=17$ June $1998 ; 10 \mathrm{~cm}=2$ July $1998 ; 15 \mathrm{~cm}=14$ July 1998; and 20 $\mathrm{cm}=30$ July 1998 .

A completely random experimental designed was used, and seedlings were grown in the greenhouse until harvest on 17 Nov. 1998. Height, trunk diameter $15 \mathrm{~cm}$ from substrate surface, shoot (all tissue above substrate) dry weight, root dry weight were measured, and root:shoot ratios were calculated. Data were analyzed using the regression procedure of Minitab, version 12 (Minitab, Inc., State College, Pa.). Optimum container depths were predicted using regression equations.

\section{Results and discussion}

In experiment one, root pruning had no effect on height, shoot dry weight, root dry weight, root length, or root:shoot ratio (data not shown), but morphology of the root system was affected. New roots appeared within 2 to 4 weeks after the radicle was pruned, creating root systems with most main lateral roots being regenerated at the cut. Main lateral roots were tough, large-diameter roots, similar to the permanent primary laterals as described by Kormanik (1986). Additional main lateral roots occasionally emerged from root tissue higher up. Root pruned plants had more total main lateral roots than plants that were not root pruned (Table 1 ). On root pruned plants, main lateral number increased with shallowness of radicle pruning.

First season posttransplant growth of sweetgum (Liquidambar styraciflua L.) (Kormanik, 1986) and northern red oak (Quercus rubra L.) (Ruehle and Kormanik, 1986) and size of loblolly pines (Pinus taeda L.) measured 7 years after transplanting (Kormanik et al., 1998) correlated positively with numbers of main lateral roots of seedling transplants. However, conflicting reports exist on the effect of root number on the longterm performance of outplanted liners. Ritchie et al. (1993) reported that root number on rooted douglas-fir [Pseudotsuga menziesii(Mirb) Franco] cuttings affected growth in nursery beds, but that differences disappeared 18 months after outplanting. Struve and McKeand (1990) found that root number was not correlated with survival or height 8 years after outplanting white pine (Pinus strobus L.) rooted cuttings. In another study, Struve et al. (1984) reported that root number of transplanted rooted cuttings of white pine were positively correlated with survival and trunk diameter at 9 and 40 years after outplanting. Benefits, if any,

Table 2. Effect of liner container depth on pin oak growth in \#2 [6 L (1.6 gal)] containers; $\mathbf{n}=10$.

\begin{tabular}{|c|c|c|c|c|c|}
\hline $\begin{array}{l}\text { Container } \\
\text { depth (cm) }\end{array}$ & $\begin{array}{c}\mathbf{H t} \\
(\mathbf{c m})\end{array}$ & $\begin{array}{c}\text { Caliper } \\
(\mathrm{cm})\end{array}$ & $\begin{array}{c}\text { Shoot dry } \\
\text { wt (g) }\end{array}$ & $\begin{array}{c}\text { Root dry } \\
\text { wt (g) }\end{array}$ & $\begin{array}{c}\text { Root:shoot } \\
\text { (wt:wt) }\end{array}$ \\
\hline 5 & 51.9 & 0.7 & 33.7 & 55.4 & 1.6 \\
\hline 10 & 75.3 & 0.9 & 44.8 & 85.3 & 2.0 \\
\hline 15 & 63.9 & 0.9 & 43.6 & 73.1 & 1.7 \\
\hline 20 & 64.2 & 0.8 & $\begin{array}{c}41.6 \\
P \text { value }^{\mathrm{z}}\end{array}$ & 60.4 & 1.5 \\
\hline Linear & 0.354 & 0.242 & 0.169 & 0.967 & 0.168 \\
\hline \multirow[t]{3}{*}{ Quadratic } & 0.003 & 0.005 & 0.005 & 0.0004 & 0.008 \\
\hline & \multicolumn{5}{|c|}{ Predicted optimum container depth $(\mathrm{cm})^{y}$} \\
\hline & 13.6 & 13.6 & 14.2 & 12.6 & 11.3 \\
\hline
\end{tabular}

${ }^{\mathrm{z}} P>\mathrm{F}$ for linear and quadratic effects from regression analysis

${ }^{y}$ Calculated from regression equations. 
to nursery growers from increased numbers of main laterals on pin oak seedlings are probably limited to short term effects, such as possibly facilitating easier harvest or increased stability in the nursery row or landscape.

Growth response of young oak liners to root pruning is reported to be species-specific. Wilson et al. (1997) found that pruning the radicle tips on swamp white oak (Quercus bicolor Willd.) increased top dry weight if done when radicles were $4 \mathrm{~cm}$ (1.6 inches) or $7 \mathrm{~cm}$ (2.8 inches) long but not at $10 \mathrm{~cm}$ (3.9 inches), whereas cherrybark oak (Quercus falcata var. pagodifolia Elliott) had reduced top weight when pruning was at $5 \mathrm{~cm}$. Our data therefore may only be relevant for pin oak.

In experiment two, a quadratic relationship existed between depth of bottomless container and plant response (Table 2). Initial production in 5 -cm-deep containers produced shortest \#2 plants with least caliper, shoot dry weight and root dry weight. The largest seedlings and the greatest root:shoot ratios were in the $10-\mathrm{cm}^{-}$ deep containers. The predicted optimum container depth ranged from 11.3 to $14.2 \mathrm{~cm}$ for the different measured growth parameters (Table 2). The observed effects could be caused by several facets of the production system. Different-depth containers air prune radicles and secondary roots at different lengths. In addition, differences in container heights confer different substrate water relations (Spomer, 1979) and larger containers contained more fertilizer. Plants were also transplanted at slightly different times to avoid a confounding potbound condition in some treatments. Although plants were transplanted at different times, this study does simulate a typical practice of transplanting oaks to larger containers as soon as they fill a pot to limit root circling. Results from experiment one indicate that other factors besides radicle pruning are probably responsible for treatment effects on growth in experiment two. Systems initially using 5 -cm-deep bottomless containers will not maximize liner growth, at least in \#2 containers.

We have presented data indicating that pruning developing radicles on pin oak seedlings does not affect shoot growth or total root length. However, depth of pruning does affect the numbers of main lateral roots formed, which may affect subsequent growth. Depth of bottomless liner containers affects subsequent growth in \#2 containers. The larger \#2 seedlings with higher root:shoot ratios that were originally grown in $10-\mathrm{cm}$-deep containers would be considered superior liners by many, although it is possible that initial differences in size of liners may disappear during production to finished sizes.

\section{Literature cited}

Arnold, M.A. and D K. Struve. 1989. Cupric carbonate controls green ash root morphology and root growth. HortScience 24:262-264.

Beeson, R.C. and R. Newton. 1992. Shoot and root responses of eighteen southeastern woody landscape species grown in cupric hydroxide-treated containers. J. Environ. Hort. 10:214-217.

Benson, A.D. and K.R. Shepherd. 1977. Effects of nursery practice on Pinus radiata seedling characteristics and field performance: II. Nursery root wrenching. N.Z. J. For. Sci. 7:68-76.

Burns, R.M. and B.H. Honkala. 1990. Silvics of North America: II. Hardwoods. USDA For. Serv. Agr. Hdbk. 654.

Duryea, M.L. and T.D. Landis. 1984. Forest nursery manual: production of forest seedlings. Martinus Nijhoff, Boston.

Duryea, M.L. and D.P. Lavender. 1982. Water relations, growth and survival of root-wrenched douglas-fir seedlings. Can. J. For. Res. 12:545-555.

Gilman, E.F. and M.E. Kane. 1990. Growth and transplantability of Magnolia grandiflora following root pruning at several growth stages. HortScience 25:74-77.

Gilman, E.F. and T.H. Yeager. 1987. Root pruning Quercus virginiana to promote a compact root system. Proc. S. Nursery Assn. Res. Conf. 32:339-341.

Harris, J.R. and J. Fanelli. 1998. Root pruning red maple and Washington hawthorn liners does not affect harvested root length after two years of field production. J. Environ. Hort. 16:127-129.

Harris, R.W., W.B. Davis, N.W. Stice, and D. Long. 1971. Root pruning improves nursery tree quality. J. Amer. Soc. Hort. Sci. 96:105-108.

Hartmann, H.T., D.E. Kester, F.T. Davies, and R.L. Geneve. 1997. Plant propagation: Principles and practices. Prentice Hall, Upper Saddle River, N.J.
Hathaway, R.D. and C.E. Whitcomb. 1977. Propagation of Quercus seedlings in bottomless containers with Osmocote. J. Arboricult. 3:208-212.

Hipps, N.A., K.H. Higgs, and L.G. Collard. 1996. The effect of irrigation and root pruning on the growth of sycamore (Acer pseudoplatanus) seedlings in nursery beds and after transplanting. J. Hort. Sci. 71:819-828.

Hipps, N.A., K.H. Higgs, and L.G. Collard. 1997. Effects of root wrenching and irrigation rate on the growth and water relations of Castanea sativa and Quercus robur seedlings in the nursery and after outplanting. Can. J. For. Res. 27:180188.

Hipps, N.A., K.H. Higgs, and L.G. Collard. 1999. Effects of root wrenching on the growth and water relations of Prunus avium and Castanea sativa seedlings in nursery beds and after outplanting. Can. J. For. Res. 29:696-704.

Kormanik, P.P. 1986. Lateral root morphology as an expression of sweetgum seedling quality. For. Sci. 32:595-604.

Kormanik, P.P., S.S. Sung, and S.J. Zarnoch. 1998. Immature loblolly pine growth and biomass accumulation: Correlations with seedlings first-order lateral roots. S. J. Appl. For. 22:117-123.

Kozlowski, T.T. and S.G. Pallardy. 1997. Growth control in woody plants. Academic Press, New York.

Mead, R., R.N. Curnow, and A.M. Hasted. 1993. Statistical methods in agriculture and experimental biology. Chapman and Hall, New York.

Niemiera, A.X., T.E. Bilderback, and C.E. Leda. 1994. Pine bark physical characteristics influence pour-through nitrogen concentrations. HortScience 29:789-791.

Pellet, H., M. Litzow, and L. Mainquist. 1980. Use of metal compounds as root pruning agents. HortScience 15:308-309.

Ritchie, G.A., Y. Tanaka, R. Meade, and S.D. Duke. 1993. Field survival and early growth of Douglas-fir rooted cuttings: Relationship to stem diameter and root system quality. For. Ecol. Mgt. 60:237256.

Rook, D.A. 1971. Effect of undercutting and wrenching on growth of Pinus radiata D. Don seedlings. J. App. Ecol. 8:477490

Ruehle, J.L. 1985. The effect of cupric carbonate on root morphology of containerized mycorrhizal pine seedlings. Can. J. For. Res. 15:586-592.

Ruehle, J.L. and P.P. Kormanik. 1986. Lateral root morphology: A potential indicator of seedling quality in northern red 
oak. USDA For. Serv. S.E. For. Expt. Sta. Res. Note 344:1-6.

Spomer, L.A. 1979. Three simple demonstrations of physical effects of soil amendments. HortScience 14:75-77.

Stinson, R.F. and C.G. Keys. 1953. Preliminary report on copper and zinc napthenate treatments to control algae growth on clay flower pots. Proc. Amer. Soc. Hort. Sci. 61:569-572.

Struve, D.K., M.A. Arnold, R. Beeson, J.M. Ruter, and W.T. Witte. 1994. The copper connection. Amer. Nurseryman 179:52-54,56-61.

Struve, D.K. and S.E. McKeand. 1990. Growth and development of eastern white pine rooted cuttings compared with seedlings through 8 years of age. Can. J. For. Res. 20:365-368.

Struve, D.K., J.T. Talbert, and S.E. McKeand. 1984. Growth of rooted cuttings and seedlings in a 40-year-old plantation of eastern white pine. Can. J. For. Res. 14:462-464.

Tanaka, T., J.D. Walstad, and J.E. Borrecco. 1976. The effect of wrenching on morphology and field performance of Douglas-fir and loblolly pine seedlings. Can. J. For. Res. 6:453-458.

Watson, G.W. 1986. Cultural practices can influence root development for better transplanting success. J. Environ. Hort. 4:32-34.

Watson, G.W. and T.D. Sydnor. 1987. The effect of root pruning on the root system of nursery trees. J. Arboricult. 13:126-130.

Wilson, T.M., R. Geneve, and W. Dunwell. 1997. The effect of early radicle pruning on root and shoot development in a red (Quercus falcata pagodifolia) and white oak (Quercus bicolor). Proc. S. Nursery Assn. Res. Conf. 42:94-97. 